\title{
深海潜水船而圧球壳の実物大規模による 熱処理法に関する実験的研究
}

\author{
正員 遠 藤 倫 正* 正員 笵野量“一”郎* \\ 正員 森 鼻 英 征 ${ }^{*}$ 正員 淵上 勝 人* \\ 豊 原 力* 正員高 野繁元 太**
}

Rescarch on Heat Treatment Procedure of Deep Submergence

Research Vehicle's Pressure Hull using Full Scale Model

by Michimasa Endo, Member

Hideyuki Morihana, Member

Tsutomu Toyohara,
Ryoichiro Sasano, Member

Katsuto Fuchigami, Member

Genta Takano, Member

\section{Summary}

In order to make oceanographic research activity more extensive, deep submergence research vchicle diving to the depth of $6000 \mathrm{~m}$ is being required in these days.

A pressure hull of the vehicle requires the material of high strength/weight ratio and good ability of manufacturing. In this point, $10 \mathrm{Ni}-8 \mathrm{Co}$ steel with the yield strength of $120 \mathrm{kgf} /$ $\mathrm{mm}^{2}$ can be said the most promising candidate for the pressure hull at pressent.

To give $10 \mathrm{Ni}-8 \mathrm{Co}$ steel enough strength and toughness, heat treatment (double-quenching and tempering) is indispensable.

From this respect, the authors conducted experimentally heat-treatment of $10 \mathrm{Ni-} 8 \mathrm{Co}$ spherical shell using a full scale model.

The report presents the description on the heat-treatment procedure, including the experimental results, which are necessary to establish the whole manufacturing procedure of a pressure hull being combined with the welding procedure already established.

\section{1 緒言}

わが国の海洋開発プロジェクトとして, 海洋科学技術 センターの $2,000 \mathrm{~m}$ 潜水調查船（しんかい2000)占が 完成し， $2,000 \mathrm{~m}$ 以浅の深海調查が可能となっている が，次のステップとして，さらに広範㧢な調查活動を可 能亡する $6,000 \mathrm{~m}$ 級深䬺潜水調查船の必要性が指摘さ れている。

この深海潜水淍查船は，乙んかい 2000 と同様の機動 性尔よび運動性能が要求されるため, 小型・軽量である ことが必須要作となる。とりわ忛, 耐圧殸恃重量/浮量 比を小さく寸る必要性から, 溞度/重量比の高い材料を 用いた，㩐造效率の高い球殸を採用する必要がある。

耐压役用材料としては, 現在, 降伏点 $120 \mathrm{kgf} / \mathrm{mm}^{2}$ 級の $10 \mathrm{Ni}-8 \mathrm{Co}$ 銅が有力な候補材である。10 Ni-8 Co 鋼交 2 回節入れ, 1 回焼もどしの調質熱処理により, 所

*三菱重工業(株)神戸造船所

**三菱重工業(株)高砂研究所
定の強度と鿒性が得られる鋼種であるため，耐王瞉の製 造過程において調質熱処理は不可欠である。

筆者らは, すでに $10 \mathrm{Ni}-8 \mathrm{Co}$ 鋼の溶接施工法として, TIG 溶接法 ${ }^{2}$ と電子ビーム溶接法 ${ }^{31}$ について実物大規模 模型を使用して，その確立を行った。本論文において は，残された課題である調質熱処理法の確立を図るた め, 想定される種々の製作工程を考虑して, 実物大規模 の模型を使用して実験的研究を行った。

その結果, $10 \mathrm{Ni}-8 \mathrm{Co}$ 鋼製耐圧球殼の製作工程で必 要な半球殼ならびに全球殼状態における調質熱処理が可 能であることを明らかにした。

\section{2 深海潜水船耐圧殻の工作法}

深海潜水調查船の耐压殼は，比強度の高い材料が採用 されるほか, 真球度を高くして重量軽減を図る必要があ るため, 工作法としては信頼性が高く，かつ加工精度の 高い方法を指向する必要がある。

$10 \mathrm{Ni}-8 \mathrm{Co}$ 鋼製耐圧殼の工作法を確立するためには， 


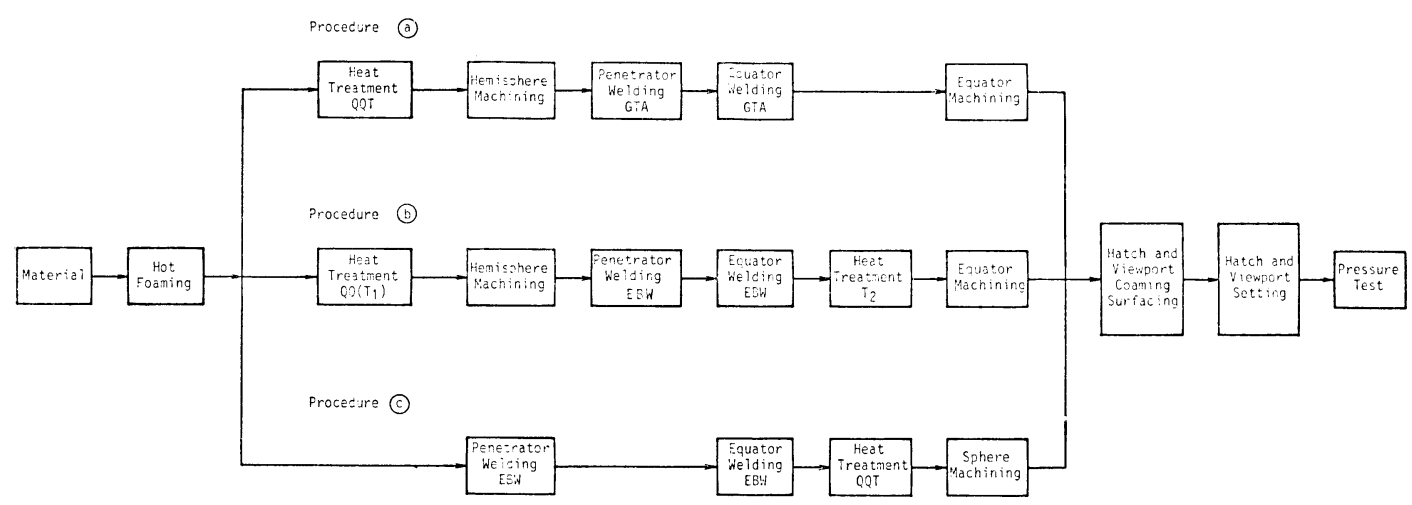

Fig. 1 Manufacturing process of pressure hull

半球熱間曲げ加工法, 調質熱処理法, 溶接法掞よび機械 加工法の要素技術の開発が必要である。要素技術中, 熱 間曲げ加工法之機械加工法は，しんかい２000で確立さ

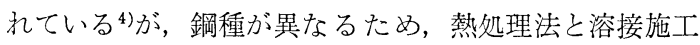
法は新たに検討する必要がある。

筆者らは, $10 \mathrm{Ni}-8 \mathrm{Co}$ 鋼の溶接法として, TIG 溶接 法と電子ビーム溶接法について，すでに実物大模型を製 作して検討した結果，いずれの溶接法も適用しうること を確認した ${ }^{23)}$ 。両者の特徴を挙げると, TIG 溶接法は, 多層溶接で施工するため, 多重熱サイクルルより溶接の ままで母材之同等の継手性能が得られるが，溶接歪が大 きくなる特徵がある。一方，電子ビーム溶接法は， 1 パ スで施工するため，溶接丕が少ないが，溶接後熱処理に より母材と同等の継手性能を得なければならないといっ た特徴がある。

今回の調質熱処理の確立にあたっては，まず耐圧殼の 加工手順を検討した。その代表的な手順を Fig. 1 に示 す。加工手順 (aは TIG 溶接法を用いるもので, しんか い2000 と同じ手順である。加工手順 (b) は電子ビーム溶 接法を用い，溶接後熱処理 $\left(\mathrm{T}_{2}\right)$ を必要とするもので, (a) 比べて真球度の向上が期待できる手順である。加工 手順 (c) は電子ビーム溶接を用い, 溶接完了後に調質熱 処理 $(\mathrm{QQT})$ を行うもので, 残留応力のない治金的に均 一な球殼が得られる手順である。

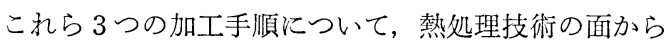
考光ると, 加工手順 (a) 2 回の燒入れ (QQ) と焼もどし (T)をすべて半球状態で行い, 加工手覑 (b) QQ を半 球状態で, Tを半球と全球状態で行い, 加工手順 (c) QQT をすべて全球状態で行らことになる。

今回の熱処理技術の研究にあたっては, $10 \mathrm{Ni}-8 \mathrm{Co}$ 鋼 の熱処理特性は熱処理シミュレーション試験により，す

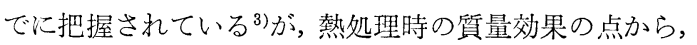
実物大規模の模型で調査することとし，6,000 m深海潜 水調查船の耐圧殸を対象とした。さらに，上述のいずれ
の加工手順に対しても対応するべく配虑し，半球状態で の燒入れ試験, 全球状態での焼入れ范よび焼もどし試験 を実施した。

\section{3 供試材と熱処理試験方法}

\section{1 供 試 材}

$6,000 \mathrm{~m}$ 深海潜水調查船の耐圧款の板厚は素材で 80 $\mathrm{mm}$ 程度が想定される。板厚 $80 \mathrm{~mm}$ の $10 \mathrm{Ni}-8 \mathrm{Co}$ 銅 と榦鋼を供試した。10 Ni-8 Co 鋼の化学組成之機械的 性質を Table 1 と Table 2 と示す。

\section{2 実物大球殼模型の形状}

$6,000 \mathrm{~m}$ 深海潜水調查船の耐圧殸はしんかい 2000 の 耐圧殼と注媇類似の形状と考兄られ, 内径は約 $2 \mathrm{~m} の$ 球殼と考兄られる。Fig. 2 亿製作した実物大球殼模型の 形状を示す。内径 $2 \mathrm{~m}$, 板厚 $80 \mathrm{~mm}$ で, $\mathrm{N}$ 半球に八ッ チ開口 1 個を, $\mathrm{S}$ 半球にのぞき空 2 個を備兄た構造とし た。 $\mathrm{N}$ 半球の一部に $10 \mathrm{Ni}-8 \mathrm{Co}$ 鋼をは方込及, この 10 Ni-8 Co 鋼仙あらかじめ Table 3 示す条件で電子ビ 一ム溶接継手を設けた。

\section{3 熱処理条件}

$10 \mathrm{Ni}-8 \mathrm{Co}$ 鋼は, 2 回焼入れ 1 回焼もどしの調質熱 処理が施されるが，機械的性質は概禖焼もどし熱処理に より決定され，焼入れ熱処理の影響の少ないことを報告 した ${ }^{3)}$ すすなわち，Fig. 3 に示すように获入机冷却速度 を $0.5^{\circ} \mathrm{C} / \mathrm{sec}$ 以上確保すると, 焼もどし条件のみによっ て, 引張特性と衝撃特性が決定される。筑もどし条件亡 引張特性との関係をテンパーパラメータで整理した結果 をFig. 4 汇示す。この图から，耐力 $120 \mathrm{kgf} / \mathrm{mm}^{2}$ を保 証する耐圧款の焼もどし条件は，テンパーパラメータで 16. $7 \times 10^{3}$ 以下，すなわち，焼もどし保持時間を 10 時 間とすると，保持温度を $522^{\circ} \mathrm{C}$ 以下とする必要がある。 な㧍, 衝撃特性は $490 \sim 530^{\circ} \mathrm{C}$ の焼もどし温度笽囲では 十分高い值が得られる。 以上のことから, 实物大模型の調筫熱処理条件とし 
Table 1 Chemical composition of $10 \mathrm{Ni}-8 \mathrm{Co}$ steel $(\%)$

\begin{tabular}{|c|c|c|c|c|c|c|c|c|}
\hline$C$ & $S i$ & $M_{n}$ & $P$ & $S$ & $N i$ & $C_{r}$ & $M_{0}$ & $C_{0}$ \\
\hline 0.13 & 0.12 & 0.20 & 0.003 & 0.002 & 9.86 & 1.95 & 1.01 & 7.90 \\
\hline
\end{tabular}

Table 2 Mechanical properties of $10 \mathrm{Ni}-8 \mathrm{Co}$ steel

\begin{tabular}{|c|c|c|c|c|c|c|}
\hline \multirow{2}{*}{$\begin{array}{l}\text { Thick- } \\
\text { ness } \\
(\mathrm{mm})\end{array}$} & \multirow{2}{*}{$\begin{array}{l}\text { Direc- } \\
\text { tion }\end{array}$} & \multicolumn{3}{|c|}{ Tensile Test } & \multicolumn{2}{|c|}{ Charpy Impact Test } \\
\hline & & $\begin{array}{c}0.2 \% \text { Proof Stress } \\
\left(\mathrm{kgf} / \mathrm{mm}^{2}\right)\end{array}$ & $\begin{array}{c}\text { Tensile Strength } \\
\left(\mathrm{kg} / / \mathrm{man}^{2}\right)\end{array}$ & $\begin{array}{c}\text { Elong. } \\
(x)\end{array}$ & $\begin{array}{c}v E-70 \\
(k g f-m)\end{array}$ & $\begin{array}{c}\text { VEo } \\
(\mathrm{kgf}-\mathrm{in})\end{array}$ \\
\hline \multirow{2}{*}{80} & L & $\begin{array}{l}128.5 \\
128.0\end{array}$ & $\begin{array}{l}145.4 \\
145.6\end{array}$ & $\begin{array}{l}18.0 \\
18.0\end{array}$ & $\begin{array}{l}14.0 \\
12.1 \\
13.5\end{array}$ & $\begin{array}{l}16.9 \\
17.6 \\
17.4\end{array}$ \\
\hline & $T$ & $\begin{array}{l}125.1 \\
126.1\end{array}$ & $\begin{array}{l}143.3 \\
143.9\end{array}$ & $\begin{array}{l}18.0 \\
18.0\end{array}$ & $\begin{array}{l}15.4 \\
14.7 \\
15.0\end{array}$ & $\begin{array}{l}16.9 \\
17.4 \\
16.4\end{array}$ \\
\hline
\end{tabular}

Table 3 Electron beam welding conditions for $10 \mathrm{Ni}-8 \mathrm{Co}$ steel

\begin{tabular}{|c|c|c|c|c|c|}
\hline $\begin{array}{c}\text { Thickness } \\
(\mathrm{mm})\end{array}$ & $\begin{array}{c}\text { Accelerating } \\
\text { Voltage } \\
(\mathrm{kV})\end{array}$ & $\begin{array}{c}\text { Beam } \\
\text { Current } \\
(\mathrm{n} / \mathrm{A})\end{array}$ & $\begin{array}{c}\text { Welding } \\
\text { Speed } \\
(\mathrm{mm} / \mathrm{min})\end{array}$ & $\begin{array}{c}\text { ab } \\
(\mathrm{D} / \mathrm{OF})\end{array}$ & $\begin{array}{c}\text { Welding } \\
\text { Position }\end{array}$ \\
\hline 80 & 90 & 400 & 200 & $\begin{array}{c}0.78 \\
(380 / 490)\end{array}$ & Horizontal \\
\hline
\end{tabular}

Table 4 Conditions of heat treatment

\begin{tabular}{|c|c|c|c|c|c|c|}
\hline No. & Component & $\begin{array}{c}\text { eat } \\
\text { Trcatment }\end{array}$ & Temperature & Time & $\begin{array}{l}\text { Required } \\
\text { Condition }\end{array}$ & $\begin{array}{c}\text { Number of } \\
\text { Measuring } \\
\text { Points }\end{array}$ \\
\hline 1 & Hemisphere & Guench & $830 \pm 20^{\circ} \mathrm{C}$ & $1.5 \mathrm{hr}$ & \multirow{3}{*}{$\begin{array}{l}\text { Cooling Rate } \\
\text { More than } \\
0.5^{\circ} \mathrm{C} / \mathrm{sec}\end{array}$} & 25 pts \\
\hline 2 & \multirow{3}{*}{ Sphere } & Ist Guench & $925 \pm 20^{\circ} \mathrm{C}$ & $1.5 \mathrm{hr}$ & & 35 pts \\
\hline 3 & & 2nd Querch & $830 \pm 20^{\circ} \mathrm{C}$ & $1.5 \mathrm{hr}$ & & $35 \mathrm{pts}$ \\
\hline 4 & & Tettiper & $505 \pm 10^{\circ} \mathrm{C}$ & $10 \mathrm{hr}$ & $\begin{array}{l}\text { Temperature } \\
505 \pm 10^{\circ} \mathrm{C}\end{array}$ & $35 \mathrm{pts}$ \\
\hline
\end{tabular}

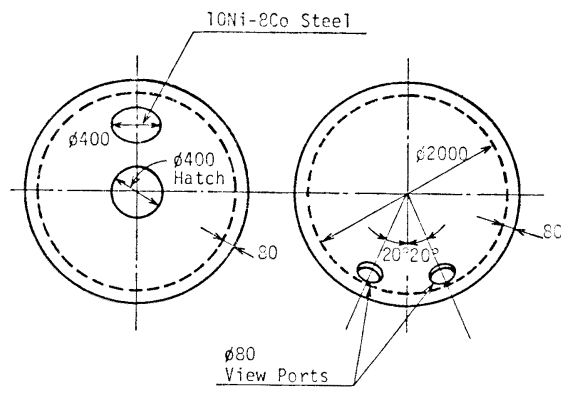

$\mathrm{N}$-hemisphere S-hemisphere

Fig. 2 Configuration of full scale model (Plan view)

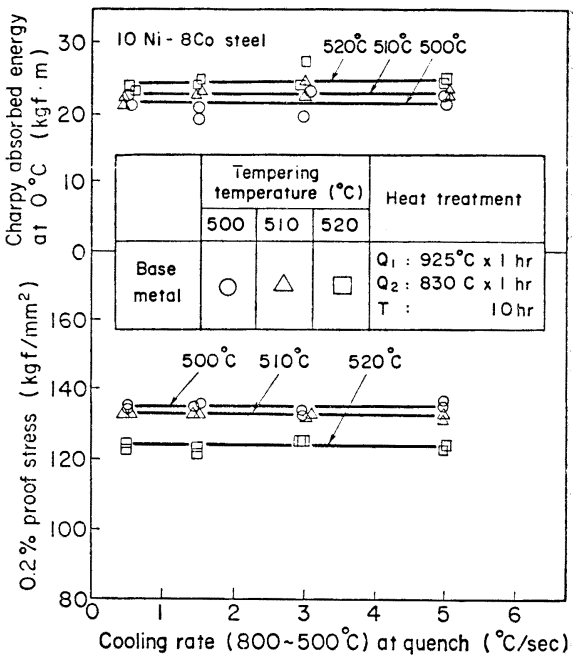

Fig. 3 Effect of cooling rate at quench on mechanical properties of $10 \mathrm{Ni}-8 \mathrm{Co}$ base metal $^{3)}$
て，焼入れ冷却速度を $0.5^{\circ} \mathrm{C} / \mathrm{sec}$ 以上，焼もどし温度を $505 \pm 10^{\circ} \mathrm{C}$ (保持時間を 10 時間とし, テンパーパラメ 一タで $\left.16.1 \times 10^{3} \sim 16.5 \times 10^{3}\right)$ を管理目標とした。 た，焼入温度は， $\mathrm{Ac}_{3}$ 点以上で第 1 回目を $925^{\circ} \mathrm{C}$, 第

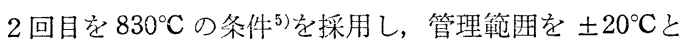
した。

2 章の耐圧殸の工作法で述べたように，6,000 m 深海 潜水調查船の附圧激の調質熱処理の時期は，半球殸状態 と全球款状態の 2 つケースが考光られる。調質熱処理 の難易度から考劣ると, 焼入れ㭙の球款内面の冷却なら びに焼もどし時の保持温度の均一性から，全球殼調質熱 処理は半球殼調啠熱処理よりもかなり困難と予想され る。

そこで，実物大模型の熱処理試験では，まず $\mathrm{N}$ 半球 の焼入れ熱処理試験を行い, $\mathrm{S}$ 半球と溶接して全球款と してから，筧入れ焼もどしの熱処理を行った。Table 4 に熱処理条件を示す。加熱はいずれも $300^{\circ} \mathrm{C}$ からの昇温
速度を $55^{\circ} \mathrm{C} / \mathrm{hr}$ とし, 所定の温度まで加熱し, 焼入れ は 1.5 時間, 焼もどしは 10 時間, 所定温度保持し, その後水そうにて冷却した。なお， $\mathrm{N}$ 半球には 25 点 （板厚中央部 13 点, 外面から $1 / 4 \mathrm{t}$ 部 6 点, 外面から $3 / 4 \mathrm{t}$ 部 6 点), $\mathrm{S}$ 半球には 10 点 (板厚中央部 5 点, 外 面から $1 / 4 \mathrm{t}$ 部 3 点, 外面から $3 / 4 \mathrm{t}$ 部 2 点) の個所に $\mathrm{CA}$ 熱電対 ( $\phi 3.2 \mathrm{~mm})$ を取付计, 保持温度と冷却中 の温度を測定した。

\section{4 熱処理試験結果}

\section{1 半球殼の焼入れ熱処理}

焼入れ熱処理では，内外面の冷却を効果的に行ら必要 がある。試験に用いた $\mathrm{N}$ 半球には, 直径 $400 \mathrm{~mm}$ の八 ッチ開口があるので，この開口部を底にして水そうに投 入する方法を採用し, 半球内面の冷却を効果的に行兄る ように配慮して焼入れ熱処理試験を行った。

熱処理の保持温度, 冷却時の温度変化を整理して, 


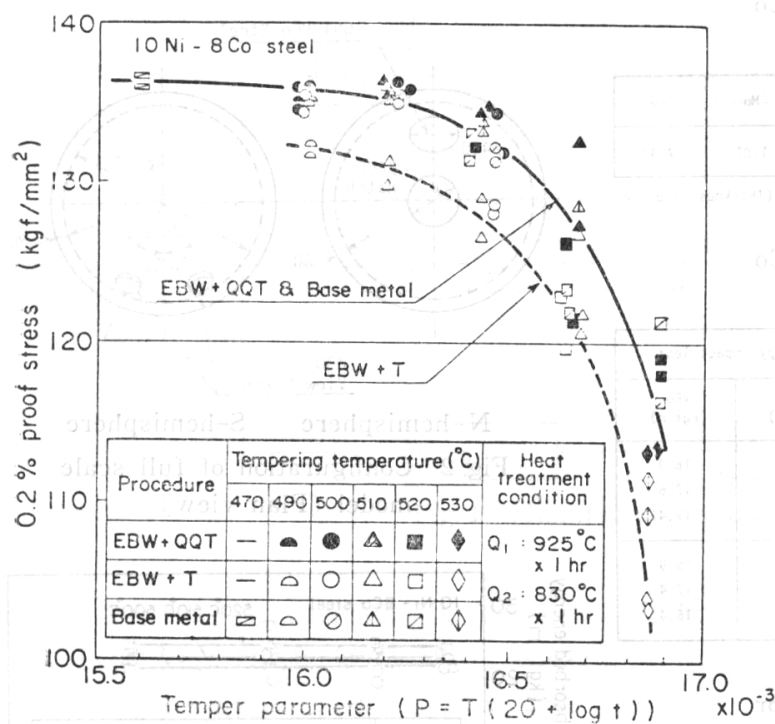

Fig. 4 Effect of temper parameter on $0.2 \%$ proof stress of $10 \mathrm{Ni}-8 \mathrm{Co}$ weld and base metal $^{3}$ )

Table 5 Results of quench (Hemisphere, $830 \pm 20^{\circ} \mathrm{C} \times 1.5 \mathrm{hr}$ )

\begin{tabular}{|c|c|c|c|c|c|}
\hline Material & Location & $\begin{array}{l}\text { Temperature } \\
\left({ }^{\circ} \mathrm{C}\right)\end{array}$ & $\begin{array}{c}\text { Temp. } \\
\text { before } \\
\text { Inmerston } \\
\left({ }^{\circ} \mathrm{C}\right) \\
\end{array}$ & $\begin{array}{c}\text { Temp. } \\
\text { Reduction } \\
\text { before } \\
\text { Inimersion } \\
\text { ( } 0 \text { ( C) }\end{array}$ & $\begin{array}{l}\text { Average } \\
\text { cool ing Rate } \\
\left(700.400^{\circ} \mathrm{C}\right) \\
\left({ }^{\circ} \mathrm{C} / \mathrm{sec}\right) \\
\end{array}$ \\
\hline \multirow{3}{*}{ Mild steel } & $1 / 2 T$ & $\begin{array}{c}834 \\
(827,846)\end{array}$ & $\begin{array}{c}805 \\
(800,818)\end{array}$ & $\begin{array}{c}28 \\
(22,34)\end{array}$ & $\begin{array}{c}4.4 \\
(3.9,5.4)\end{array}$ \\
\hline & $1 / 4 T$ & $\begin{array}{c}832 \\
(830,833)\end{array}$ & $\begin{array}{c}797 \\
(792,800)\end{array}$ & $\begin{array}{c}35 \\
(32,38)\end{array}$ & $\begin{array}{l}3.9 \\
(3.2,4.8)\end{array}$ \\
\hline & $3 / 4 \mathrm{~T}$ & $\begin{array}{c}830 \\
(325,838)\end{array}$ & $\begin{array}{c}793 \\
(792.796)\end{array}$ & $(33,42)$ & $\begin{array}{c}3.9 \\
(3.6,4.3)\end{array}$ \\
\hline \multirow{3}{*}{$\begin{array}{c}\text { IONi-8Co } \\
\text { Steel }\end{array}$} & $1 / 2 T$ & $\begin{array}{c}844 \\
(340,847)\end{array}$ & $\begin{array}{c}805 \\
(799,810)\end{array}$ & $\begin{array}{l}39 \\
(37,41)\end{array}$ & $\begin{array}{c}3.2 \\
(3.1,3.2)\end{array}$ \\
\hline & $1 / 4 \mathrm{~T}$ & $\begin{array}{c}840 \\
(840,840)\end{array}$ & $\begin{array}{c}799 \\
(799,799)\end{array}$ & $\begin{array}{c}41 \\
(41,41)\end{array}$ & $\begin{array}{c}3.5 \\
(3.4,3.5)\end{array}$ \\
\hline & $3 / 4 T$ & $\begin{array}{c}840 \\
(840,840)\end{array}$ & $\begin{array}{c}790 \\
(787,792)\end{array}$ & $\begin{array}{c}51 \\
(48,53)\end{array}$ & $\begin{array}{c}4.9 \\
(4.8,4.9)\end{array}$ \\
\hline
\end{tabular}

Note: Showing Average Value, Minimum and Maximum one in ().

Table 5 に示す。焼入れ保持温度は $830+\frac{17}{2}{ }^{\circ} \mathrm{C}$ で目標精 度を満足し, 板厚測定位直による影響は少ない。炉出し から水没までの搬出中の温度低下は，22〜 53ㄷ C゙あり，

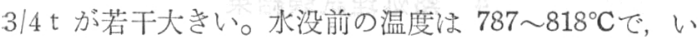
ずれの計测点に和いてもオーステナイト組織の温度であ った。

$700 \sim 400^{\circ} \mathrm{C}$ に未打る平均冷却速度は, 板厚測定位置 飞よる差は少なく，3. 1 5. $4^{\circ} \mathrm{C} / \mathrm{sec}$ である。材質による 差をみると, $10 \mathrm{Ni}-8 \mathrm{Co}$ 鋼は $3.1 \sim 4.9^{\circ} \mathrm{C} / \mathrm{sec}$, 軟鋼は $3.2 \sim 5.4^{\circ} \mathrm{C} / \mathrm{sec}$ の範囲であり, 目標の $0.5^{\circ} \mathrm{C} / \mathrm{sec}$ 以上 をいずれも十分満足した。

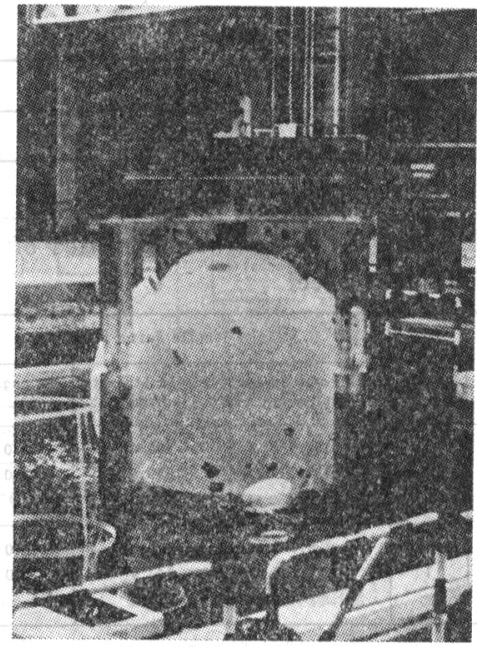

Fig. 5 Heat treatment of spherical model

\section{2 全球亮の焼入れ熱処理}

全球款状態で調質熱処理を行う場合, 焼入れ時の 冷却速度を確保するため, 内面の水冷を効果的に行 ら必要がある。球内部に素早く水を入机ることと, 内部で発生した水蒸気を外部へ放出させることが重 要となる。そこでハッチ開口部から水が入り，のぞ き空の開口部から水蒸気が放散するよらに球殸を水 没させ焼入れ熱処理を行った。また熱処理時の変 形を防止するための治具を装備した。この状況を Fig. 5 に示す。

Table 6 に, $925^{\circ} \mathrm{C}$ からの第 1 回焼入れ熱処理時 の試験結果を, Table 7 に, $830^{\circ} \mathrm{C}$ からの第 2 回焼 入れ熱処理時の試験結果を示す。筞入れ保持温度は $925_{-27}^{+16{ }^{\circ} \mathrm{C}}, 830_{-30}^{+9}{ }^{\circ} \mathrm{C}$ の範因であった。低温側に一部 目標值を下回方個所があり,これは主に外面から 3/4t の位圆であった。全球殼状態では外面からの 加熱であるため, 外面汇比較して内面の温度が低 く, 今回 $1 / 2 \mathrm{t}$ の位置の熱電詨で温度制御していた ため，内面側が目標值をはずれたことが主な原因と 考党られる。しかし，㜔入れ時の温度がオーステナ イト化温度以上であればよいので，特に問題はないと判 断した。

$10 \mathrm{Ni}-8 \mathrm{Co}$ 鋼の板厚中央部に和ける $700 \sim 400^{\circ} \mathrm{C}$ 間の 平均冷却速度は, $920^{\circ} \mathrm{C}$ 焼入れの場合で $3.1 \sim 3.2^{\circ} \mathrm{C} / \mathrm{sec}$, $830^{\circ} \mathrm{C}$ 暁入れの場合で $3.0 \sim 3.2^{\circ} \mathrm{C} / \mathrm{sec}$ であり, 筧入温 度による差はほとんどなかった。梞たこの冷却速度は半 球状態の焼入れ時とほぼ同じ值であった。

軟鋼の板厚中央部に和汀る平均泠却速度注 $925^{\circ} \mathrm{C}$ 焼入 れの場合で $2.2 \sim 3.6^{\circ} \mathrm{C} / \mathrm{sec}, 830^{\circ} \mathrm{C}$ 焼入れの場合で 2.3 〜 $6.1^{\circ} \mathrm{C} / \mathrm{sec}$ であった。いずれの場合も泠却速度の最も 遅い部分は，水没の遅い上部ののでき空開口近傍であっ 
Table 6 Results of 1st quench (Sphere, $925 \pm 20^{\circ} \mathrm{C} \times 1.5 \mathrm{hr}$ )

\begin{tabular}{|c|c|c|c|c|c|}
\hline Sterial & Location & $\begin{array}{c}\text { Temperature } \\
(c)\end{array}$ & $\begin{array}{c}\text { Temp. } \\
\text { before } \\
\text { Immersion } \\
\left({ }^{\circ} \mathrm{C}\right)\end{array}$ & $\begin{array}{l}\text { Temp. } \\
\text { Reduct ion } \\
\text { before } \\
\text { Imersion } \\
\left({ }^{\circ} \mathrm{C}\right)\end{array}$ & $\begin{array}{c}\text { Average } \\
\text { Cooling Rate } \\
\left(700.400^{\circ} \mathrm{c}\right) \\
\left({ }^{\circ} \mathrm{C} / \mathrm{sec}\right)\end{array}$ \\
\hline \multirow{3}{*}{ Mild Steel } & $1 / 2 T$ & $\begin{array}{c}920 \\
(905,935)\end{array}$ & $\begin{array}{c}902 \\
(888,920)\end{array}$ & $\begin{array}{c}19 \\
(10,29)\end{array}$ & $\begin{array}{c}2.9 \\
(2.2,3.6)\end{array}$ \\
\hline & $1 / 4 \mathrm{~T}$ & $\begin{array}{c}915 \\
(905,927)\end{array}$ & $\begin{array}{c}881 \\
(868,898)\end{array}$ & $(24,50)$ & $\begin{array}{c}2.9 \\
(2.2,3.4)\end{array}$ \\
\hline & $3 / 4 T$ & $\begin{array}{c}913 \\
(893,931)\end{array}$ & $\begin{array}{c}905 \\
(890,919)\end{array}$ & $\left(3^{9}, 12\right)$ & $\begin{array}{c}2.7 \\
(1.8,3.8)\end{array}$ \\
\hline \multirow{3}{*}{$\begin{array}{c}10 \%-8 C o \\
\text { steel }\end{array}$} & $1 / 2 \mathrm{~T}$ & $\begin{array}{c}931 \\
(930,931)\end{array}$ & $\begin{array}{c}919 \\
(917,918)\end{array}$ & $(12,14)$ & $\begin{array}{c}3.2 \\
(3.1,3.2)\end{array}$ \\
\hline & $1 / 4 \mathrm{~T}$ & $\begin{array}{c}933 \\
(931,934)\end{array}$ & $\begin{array}{c}904 \\
(903,905)\end{array}$ & $\begin{array}{c}29 \\
(28,29)\end{array}$ & $\begin{array}{c}3.6 \\
(3.5,3.6)\end{array}$ \\
\hline & $3 / 4 \mathrm{~T}$ & $\begin{array}{c}931 \\
(931,931)\end{array}$ & $\begin{array}{c}914 \\
(914,914)\end{array}$ & $(17,17)$ & $\begin{array}{c}3.9 \\
(3.8,3.9)\end{array}$ \\
\hline
\end{tabular}

Note: Showing Average Value, Minimum and Maximum one in ( ).

Table 7 Results of 2 nd quench (Sphere, $830 \pm 20^{\circ} \mathrm{C} \times 1.5 \mathrm{hr}$ )

\begin{tabular}{|c|c|c|c|c|c|}
\hline Material & Location & $\begin{array}{c}\text { Temperature } \\
(\mathrm{C})\end{array}$ & $\begin{array}{l}\text { Temp. } \\
\text { tefore } \\
\text { Imersion } \\
\left({ }^{\circ} \mathrm{C}\right)\end{array}$ & $\begin{array}{l}\text { Temp. } \\
\text { Reduct ion } \\
\text { before } \\
\text { Immers ion } \\
\left({ }^{\circ} \mathrm{C}\right)\end{array}$ & $\begin{array}{c}\text { Average } \\
\text { Cooling Rate } \\
\left(7 \mathrm{wr}^{\circ}-400^{\circ} \mathrm{C}\right) \\
\left({ }^{\circ} \mathrm{C} / \mathrm{sec}\right)\end{array}$ \\
\hline \multirow{3}{*}{ Mild Steel } & $1 / 2 i$ & $\begin{array}{c}823 \\
(310,836)\end{array}$ & $\begin{array}{c}809 \\
(701,829)\end{array}$ & $\begin{array}{c}14 \\
(7,20)\end{array}$ & $\begin{array}{c}4.7 \\
(2.3,6.1)\end{array}$ \\
\hline & $1 / 4 \mathrm{~T}$ & $\begin{array}{c}817 \\
(800,835)\end{array}$ & $\begin{array}{c}791 \\
(770,816)\end{array}$ & $\begin{array}{c}27 \\
(19,33)\end{array}$ & $\begin{array}{c}4.2 \\
(3.0,5.1)\end{array}$ \\
\hline & $3 / 4 T$ & $\begin{array}{c}816 \\
(800,930)\end{array}$ & $\begin{array}{c}808 \\
(790,323)\end{array}$ & $(2,8)$ & $\begin{array}{c}5.7 \\
(1.7,9.2)\end{array}$ \\
\hline \multirow{3}{*}{$\begin{array}{c}\text { IONi-8Co } \\
\text { Steel }\end{array}$} & $1 / 2 T$ & $\begin{array}{c}838 \\
(837,939)\end{array}$ & $\begin{array}{c}\varepsilon 26 \\
(025,827)\end{array}$ & $(12,12)$ & $\begin{array}{c}3.1 \\
(3.0,3.2)\end{array}$ \\
\hline & $1 / 4 \mathrm{~T}$ & $\begin{array}{c}835 \\
(834,835)\end{array}$ & $\begin{array}{c}815 \\
(813,816)\end{array}$ & $\begin{array}{c}20 \\
(18,22)\end{array}$ & $\begin{array}{c}3.6 \\
(3.6,3.6)\end{array}$ \\
\hline & $3 / 4 \mathrm{~T}$ & $\begin{array}{c}832 \\
(830,833)\end{array}$ & $\begin{array}{c}821 \\
(813,823)\end{array}$ & $\begin{array}{c}11 \\
(10,12)\end{array}$ & $\begin{array}{l}4.6 \\
(4.6)\end{array}$ \\
\hline
\end{tabular}

Note: Showing Average Value, Minimum and Maximum one in ( ).

た。半球状態の燒入れと比較すると, 平均值はほぼ同じ であるが，全球整の方が場听による差が大きいといえ る。しかしこれらの冷却速度はいずれも目標の $0.5^{\circ} \mathrm{C} /$ sec 以上を十分に满足した。

\section{3 全球款の焼もどし熱処理}

3.3 節で述べたように $10 \mathrm{Ni}-8 \mathrm{Co}$ 鋼では焼もどし温 度の管理が最も重要である。そのため, 所定温度保持は 実体温度を熱電刘でモニタリングしながら，加熟バーナ 学制御して行った。

Table 8 に䓵もどし熱处理试験結果定示す。保持温度

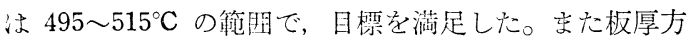
向の測定位置閻の差はほとしど生じなかった。このこと から全球状態淿いても目標条件内で烧もどし熱処理が 可能であることがわかった。
Table 8 Results of tempor Sphere, $505 \pm$ $10^{\circ} \mathrm{C} \times 10 \mathrm{hr}$ )

\begin{tabular}{|c|c|c|c|c|c|}
\hline Màterial & Location & $\begin{array}{c}\text { Temperature } \\
\left({ }^{\prime}(c)\right)\end{array}$ & $\begin{array}{l}\text { Temp. } \\
\text { before } \\
\text { Inersion } \\
\left({ }^{\circ} \mathrm{C}\right)\end{array}$ & $\begin{array}{l}\text { Terso. } \\
\text { keouction } \\
\text { before } \\
\text { inersion } \\
\left({ }^{\circ} \mathrm{C}\right)\end{array}$ & $\begin{array}{c}\text { Average } \\
\text { Col ing Rate } \\
\left(450,200^{\circ} \mathrm{C}\right) \\
\left({ }^{\circ} \mathrm{C} / \mathrm{sec}\right)\end{array}$ \\
\hline \multirow{3}{*}{ Mild Steel } & $1 / 2 T$ & $\begin{array}{c}505 \\
(495,515)\end{array}$ & $\begin{array}{c}498 \\
(483,510)\end{array}$ & $(5,15)$ & $\begin{array}{c}4.0 \\
(3.1,4.5)\end{array}$ \\
\hline & $i / 4 \mathrm{~T}$ & $\begin{array}{c}496 \\
(495,508)\end{array}$ & $\begin{array}{c}487 \\
(480,497)\end{array}$ & $\stackrel{9}{(5,12)}$ & $\begin{array}{c}3.8 \\
(3.1,4.4)\end{array}$ \\
\hline & $3 / 4 T$ & $\begin{array}{c}502 \\
(4,95,515)\end{array}$ & $\begin{array}{c}096 \\
(433,512)\end{array}$ & $(3,12)$ & $\begin{array}{c}3.6 \\
(3.3,3.8)\end{array}$ \\
\hline \multirow{3}{*}{$\begin{array}{l}\text { loni-8Co } \\
\text { Steel }\end{array}$} & $1 / 2 \mathrm{~T}$ & $\begin{array}{c}514 \\
(512,515)\end{array}$ & $\begin{array}{c}507 \\
(505,509)\end{array}$ & $(3,70)$ & $\begin{array}{c}2.5 \\
(2.5,2.5)\end{array}$ \\
\hline & $1 / 4 T$ & $\begin{array}{c}512 \\
(512,512)\end{array}$ & $\begin{array}{c}505 \\
(505,505)\end{array}$ & $\begin{array}{c}7 \\
(7,7)\end{array}$ & $\begin{array}{c}2.6 \\
(2.6,2.6)\end{array}$ \\
\hline & $3 / 4 T$ & $\begin{array}{c}512 \\
(512,512)\end{array}$ & $\begin{array}{c}503 \\
(500,505)\end{array}$ & $\begin{array}{c}10 \\
(7,12)\end{array}$ & $\begin{array}{c}3.1 \\
(2.9,3.2)\end{array}$ \\
\hline
\end{tabular}

Note: Showing Average Value, Minimum and Maximum one in ( ).

\section{5 解 体 試 験}

\section{1 熱処理による変形}

調質熱処理において，熱処理により素材の所要の 機械的性質を得ることが最も重要で方るが，熱閏明 げ加工時の余肉の決定と, 熱処理後の機械加工時の 切削代の確保のために，熱処理による変形量をも把 握する必要がある。全球款状態に和ける調質熱処理 には，変形防止治具を用いた。変形を適正に防止し うることを確認するため，球殼の各部の位置で熱処 理の前後で形状計測を行い, 熱処理による変形量 を調べた。2回燅入れによる半径の変化は平均で $5 \mathrm{~mm}$ の減少であり, その後の莾もどしによる変化 は平均 $0.2 \mathrm{~mm}$ の增加であった。

この結果, 材質差による変態挙動に伴う変形量の 差が全球款の変形量汇影響するものと考えられる が，全球殼状態で調質熱処理を行っても，大学な変形が なく，熱処理後の機械加工のための切削代が十分確保で きるとの見通しが得られた。

\section{2 機 械的性 質}

调啠熱処理を施した $10 \mathrm{Ni}-8 \mathrm{Co}$ 鋼とこの霆子ビーム 溶接継手から引張試験片とシャルピー衝撃試験片を採取 して，機械的性質を調查した。

引張試験片形状は JIS Z 2201 の 4 号試験片に隼じた。 时材と継手引張試験片は直径 $8 \mathrm{~mm}$ のつば付きとし, 溶接金属引㲀試験片は直径 $4 \mathrm{~mm}$ とした。試騟結果を Table 9 に示す。0.2\% 酎力は目材で $126.0 \sim 129.2 \mathrm{kgf} /$ $\mathrm{mm}^{2}$, 溶接金属で 133.2 135.2 $\mathrm{kgf} / \mathrm{mm}^{2}$ で㐫り, 若 干溶接金属が高目であった。また,引張強さは母材, 溶接 金属，溶接継手ともほぼ等しく 145.8〜150.0 kgf $/ \mathrm{mm}^{2}$ 
Table 9 Results of mechanical properties of $10 \mathrm{Ni}-8$ Co steel (Base metal and welded zone)

\begin{tabular}{|c|c|c|c|c|c|c|c|c|c|c|c|}
\hline \multirow{3}{*}{ Location } & \multirow{3}{*}{ Direction } & \multicolumn{4}{|c|}{ Tensile Test } & \multicolumn{6}{|c|}{ Charpy Impact Test } \\
\hline & & \multirow{2}{*}{$\begin{array}{l}0.2 \% \text { Proof } \\
\text { Stress } \\
\left(\mathrm{kgf} / \mathrm{mm}^{2}\right)\end{array}$} & \multirow{2}{*}{$\begin{array}{l}\text { Tensile } \\
\text { Strength } \\
\left(\mathrm{kgf} / \mathrm{mm}^{2}\right)\end{array}$} & \multirow{2}{*}{$\begin{array}{c}\text { Elong. } \\
(s)\end{array}$} & \multirow{2}{*}{$\begin{array}{c}\text { Reduc. } \\
(\%)\end{array}$} & \multicolumn{6}{|c|}{ Charpy Absorbed Energy $(1) \quad(\mathrm{kgf} \cdot \mathrm{m})$} \\
\hline & & & & & & $0^{\circ} \mathrm{C}$ & $-20^{\circ} \mathrm{C}$ & $-50^{\circ} \mathrm{C}$ & $-70^{\circ} \mathrm{C}$ & $-96^{\circ} \mathrm{C}$ & $-150^{\circ} \mathrm{C}$ \\
\hline \multirow{2}{*}{$\begin{array}{l}\text { Rase } \\
\text { hetal }\end{array}$} & $\mathrm{L}$ & $\begin{array}{l}126.0 \\
126.0\end{array}$ & $\begin{array}{l}146.6 \\
147.2\end{array}$ & $\begin{array}{l}16.2 \\
15.0\end{array}$ & $\begin{array}{l}75.0 \\
73.7\end{array}$ & 19.7 & 18.7 & 15.7 & 14.4 & 14.2 & 10.3 \\
\hline & c & $\begin{array}{l}127.7 \\
129.2\end{array}$ & $\begin{array}{l}145.8 \\
146.0\end{array}$ & $\begin{array}{l}14.5 \\
15.0\end{array}$ & $\begin{array}{l}72.5 \\
73.7\end{array}$ & 18.3 & 17.5 & 15.5 & 12.9 & 11.8 & 9.8 \\
\hline \multirow{2}{*}{$\begin{array}{l}\text { Weld } \\
\text { Zone }\end{array}$} & $\begin{array}{l}\text { Weld } \\
\text { Metal }\end{array}$ & $\begin{array}{l}135.2 \\
133.2\end{array}$ & $\begin{array}{l}148.4 \\
148.8\end{array}$ & $\begin{array}{l}21.4 \\
21.4\end{array}$ & $\begin{array}{l}72.8 \\
72.8\end{array}$ & 16.0 & 16.2 & 13.0 & 12.9 & 11.7 & 8.6 \\
\hline & $\begin{array}{l}\text { Welded } \\
\text { Joint }\end{array}$ & $\begin{array}{l}127.8 \\
127.2\end{array}$ & $\begin{array}{l}148.2 \\
150.0\end{array}$ & $\begin{array}{l}14.7 \\
15.0\end{array}$ & $\begin{array}{l}69.7 \\
72.5\end{array}$ & - & - & - & - & - & - \\
\hline
\end{tabular}

(1) Average of 3 specimens

であり，従来のデータ3)とほぼー致した。

シャルピー衝撃試験片形状は JIS Z 2202 の 4 号試験 片を用いた。シャルピー吸収エネルギーは，母材が $0{ }^{\circ} \mathrm{C}$ で $18.3 \sim 19.7 \mathrm{kgf}-\mathrm{m},-70^{\circ} \mathrm{C}$ で $12.9 \sim 14.4 \mathrm{kgf}-\mathrm{m}$ で あり，溶接金属は $0^{\circ} \mathrm{C}$ で $16.6 \mathrm{kgf}-\mathrm{m},-70^{\circ} \mathrm{C}$ で 12.9 $\mathrm{kgf}-\mathrm{m}$ であった。母材之溶接金属の值は注涪同等で, いずれも良好な值であった。

この結果, 全球殼状態に执いて目標とする調質熱処理 が実施できることが確認された。

\section{6 考察}

耐圧球殼の直径は板厚に比べて十分大きいので, 球殼 を無限平板之仮定すると, 燒入れ熱処理の冷却現象は一 次元熱伝導問題となり, この関係式は (1) 式のように なる。

$$
\frac{\partial \theta}{\partial t}=K \frac{\partial^{2} \theta}{\partial x^{2}}
$$

初期条件 : $t=0$ のとき $-l \leqq x \leqq l$ に执いて $\theta=\theta_{0}$ 境界条件 : $x=0$ に打いて $\frac{\partial \theta}{\partial x}=0$

この解を無次元化表示すると（2）式のようになる。

$$
\frac{\theta_{0}-\theta}{\theta_{0}-\theta_{s}}=2 \sum_{n=1}^{\infty} \frac{\sin \delta_{n} \cos \delta_{n} X}{\delta_{n}+\sin \delta_{n} \cos \delta_{n}} e^{-\delta_{n}{ }^{2} N_{F}}
$$

ただし

$\theta=$ 温度, $\theta_{0}$ =初期温度, $\theta_{s}=$ 冷却液温度 (水温),

$X=\frac{x}{l}$ (無次元座標),$x=$ 板厚方向座標, $t=$ 時間,

$2 l=$ 板厚, $K=$ 熱抎散率, $c=$ 比熱, $\rho=$ 比重,

$\lambda=$ 熱伝導率, $\alpha=$ 熱伝達係数, $N_{F 0}=\frac{K}{l^{2}} t$,

$N_{B 1}=\frac{\alpha}{\lambda} l$ (Biot 数), $\delta_{n}$ は $\frac{\delta_{n}}{N_{B 1}}=\cot \delta_{n}$ の正根

冷却曲線の計算にあたっては, 材料の物理定数抏よび 材料之水之の熱伝達俰数が問題となる。これらの值は冷 却中の各温度によって变化する。例光ば軟鋼 $(\mathrm{C}=0.06$
$\%, \mathrm{Mn}=0.4 \%$ ) の場合, $\lambda$ は $800^{\circ} \mathrm{C} て ゙ ~ 28.5 \mathrm{~W} / \mathrm{mK}$, $600^{\circ} \mathrm{C}$ で $36.4 \mathrm{~W} / \mathrm{mK}, 400^{\circ} \mathrm{C}$ で $45.2 \mathrm{~W} / \mathrm{mK}$ となる6)。 ここでは 700〜 400 $\mathrm{C}$ の間の冷却速度を検討しているの で, 計算を簡略化するために物理定数は $500^{\circ} \mathrm{C}$ の值を使 用した。10 Ni-8 Co 鋼については笑测値がないため,

$3.5 \mathrm{Ni}$ 鋼, $9 \mathrm{Ni}$ 鋼, $18 \mathrm{Ni}$ マルェージング鋼のデータ を $\mathrm{Ni}$ 量で整理し， Ni 量が $10 \%$ となる值を使用し た。これらのことより, 軟鋼については $\lambda=40 \mathrm{~W} / \mathrm{mK}$, $=0.15 \mathrm{kcal} / \mathrm{kg}^{\circ} \mathrm{C}=630 \mathrm{~W} / \mathrm{kgK}, \rho=7.8 \mathrm{~g} / \mathrm{cm}^{3}, 10 \mathrm{Ni}-$ Co 鋼については $\lambda=30 \mathrm{~W} / \mathrm{mK}, c=630 \mathrm{~W} / \mathrm{kgK}, \rho=$ $7.8 \mathrm{~g} / \mathrm{cm}^{3}$ を用いた。

次に熱伝達係数であるが, 接入れ冷却時汇は膜沸騰, 遷移沸騰，核沸騰，対流の領域を通る。しかし，ここで 問題としているような $700 \sim 400^{\circ} \mathrm{C}$ の閂の温度域では膜 沸騰の領域であり, 熱伝達係数もほ汸一定となる7)。従 来の水冷却時の熱伝達係数の湘定絬果は 800 12,000 $\mathrm{w} / \mathrm{m}^{2} \mathrm{~K}$ となっている7)。そこで熱伝達倸数を 800 $10,000 \mathrm{w} / \mathrm{m}^{2} \mathrm{~K}$ の間で変化させて板厚中央部曲線を Schneider の表8)より求めた。

搬出中の温度降下を考虑して, $900^{\circ} \mathrm{C}$ から水泠した場 合の, $10 \mathrm{Ni}-8 \mathrm{C} 0$ 鋼の泠却曲線を Fig. 6 に, 軟鋼の彾 却曲線を Fig. 7 に示す。また, $800^{\circ} \mathrm{C}$ から水冷した場合 の $10 \mathrm{Ni}-8 \mathrm{C} 0$ 鋼の冷却曲線を Fig. 8 飞示す。同様に $800^{\circ} \mathrm{C}$ から水冷した場合の軟鋼の泠却曲線も作成し, こ れらの図から $700 \sim 400^{\circ} \mathrm{C}$ の間の平均冷却速度を計算し た。得られた結果を Fig. 9 と Fig. 10 に熱伝達係数を 横軸として整理して示す。

$7 \mathrm{C} 0 \sim 400^{\circ} \mathrm{C}$ の平均冷却速度は, 熱伝逢保数の增加に 伴い速くなるが，焼入温度が $900^{\circ} \mathrm{C}$ と $800^{\circ} \mathrm{C}$ では大き な差はなかった。また軟鋼の方が $10 \mathrm{Ni}-8 \mathrm{Co}$ 鋼に比べ て, 熱伝導率が高く, 平均冷却速度も $0.3 \sim 0.8^{\circ} \mathrm{C} / \mathrm{sec}$ 速 い值であった。

今回の実験結果では冷却速度の平均値は $10 \mathrm{Ni}-3 \mathrm{Co}$ 


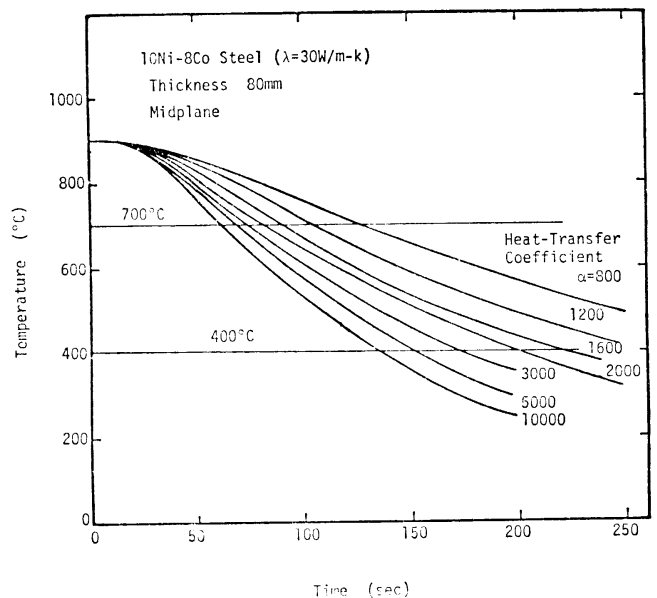

Fig. 6 Cooling diagram of quench (Calcurated, $10 \mathrm{Ni}-8 \mathrm{Co}$, Q. temp. $\left.900^{\circ} \mathrm{C}\right)$

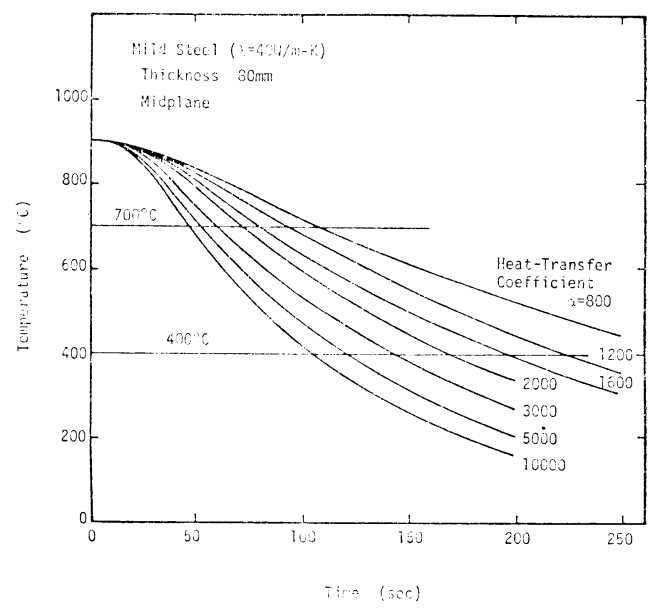

Fig. 7 Cooling diagram of quench (Calcurated, Mild steel, Q. temp. $990^{\circ} \mathrm{C}$ )

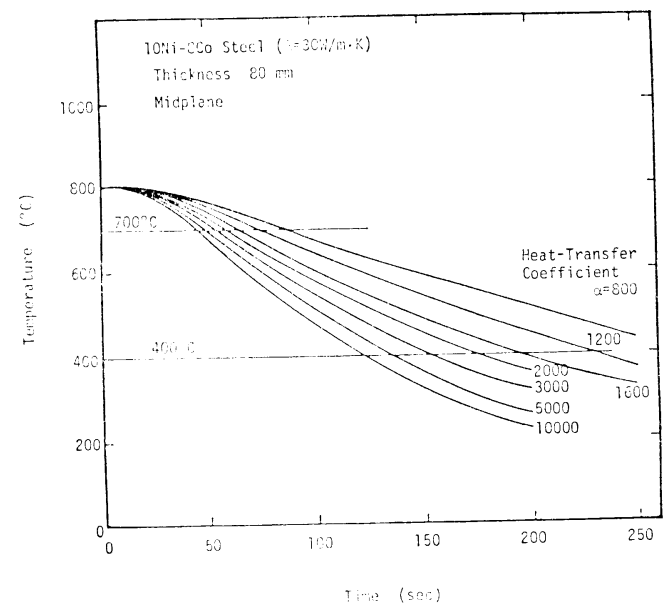

Fig. 8 Cooling diagram of quench (Calcurated, $\left.10 \mathrm{Ni}-8 \mathrm{Co}, \mathrm{Q} . \mathrm{temp} .800^{\circ} \mathrm{C}\right)$

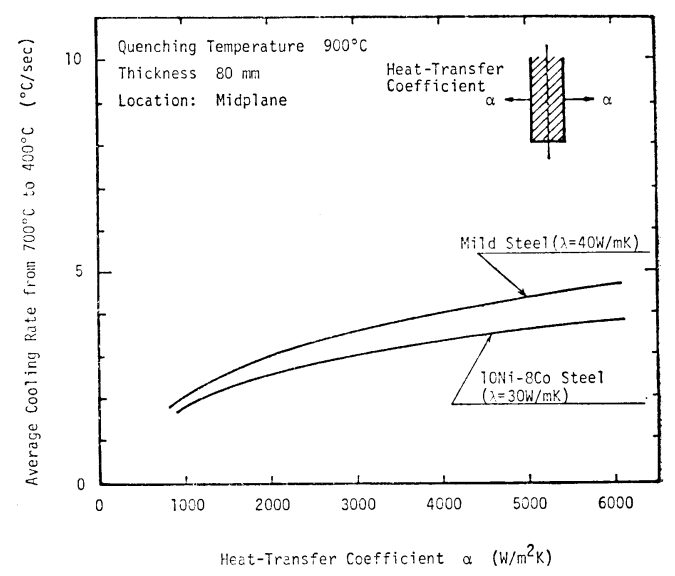

Fig. 9 Relationship between cooling rate and heat transfer coefficient at quench $\left(900^{\circ} \mathrm{C}\right)$

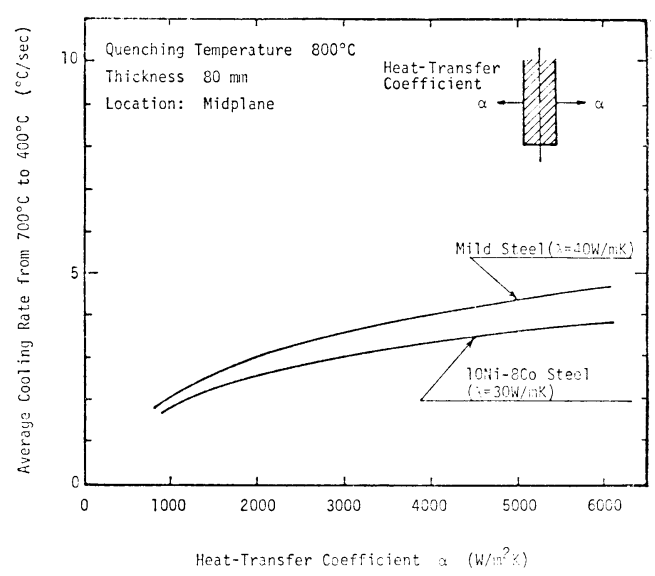

Fig. 10 Relationship between cooling rate and heat transfer coefficient at quench $\left(800^{\circ} \mathrm{C}\right)$

鋼の場合, $925^{\circ} \mathrm{C}$ 焼入れで $3.2^{\circ} \mathrm{C} / \mathrm{sec}, 830^{\circ} \mathrm{C}$ 焼入れで $3.1^{\circ} \mathrm{C} / \mathrm{sec}$, 靯鋼の場合, $925^{\circ} \mathrm{C}$ 焼入れで $2.9^{\circ} \mathrm{C} / \mathrm{sec}$, $830^{\circ} \mathrm{C}$ 焼入れで $4.7^{\circ} \mathrm{C} / \mathrm{sec}$ であった。この值と計算䋨 果から熱伝達係数を推测すると， $10 \mathrm{Ni}-8 \mathrm{Co}$ 鋼は $925^{\circ} \mathrm{C}$ 焼入れ, $830^{\circ} \mathrm{C}$ 焼入れ共に約 $4,000 \mathrm{~W} / \mathrm{m}^{2} \mathrm{~K}$ となり, 乙 んかい 2000 で使用した NS 90 鋼の約 $3,800 \mathrm{~W} / \mathrm{m}^{2} \mathrm{~K}$ に近い值で㐫った。軟鋼については， $925^{\circ} \mathrm{C}$ 焼入れで約 $2,000 \mathrm{~W} / \mathrm{m}^{2} \mathrm{~K}, 830^{\circ} \mathrm{C}$ 穘入れで約 $6,000 \mathrm{~W} / \mathrm{m}^{2} \mathrm{~K}$ となっ た。しんかい 2000 の実物大模型製作時の軟鋼製半球殸 の $780^{\circ} \mathrm{C}$ 焼入れに打ける熱伝達数は約 $8,000 \mathrm{~W} / \mathrm{m}^{2} \mathrm{~K}$ であり，焼入温度が高くなるにつれて熱伝達係数が低く なっている。

このように軟鋼において熱伝達係数に大きな差がでた ので，表面に錆が付着した場合の影響を検討した。すな わち，10 Ni-8Co 鋼に扮いては表面の錆の付着状況は $925^{\circ} \mathrm{C}$ 焼入れと $830^{\circ} \mathrm{C}$ 焼入れであまり差がみられなか 
ったが，軟鋼に拈いては錆の厚さが， $925^{\circ} \mathrm{C}$ で約 0.5 $\mathrm{mm}, 830^{\circ} \mathrm{C}$ で約 $0.2 \mathrm{~mm}$ と大きな差があった。このよ らに表面に錆が付着した場合の有効熱伝達係数は（3） 式のよらに表わされている。

$$
\frac{1}{\alpha_{e}}=\frac{1}{\alpha_{1}}+\frac{l_{1}}{\lambda_{1}}
$$

ただし

$$
\begin{aligned}
& \alpha_{e}=\text { 有効熱伝達係数 } \\
& \alpha_{1}=\text { 表面からの熱伝達係数 } \\
& l_{1}=\text { 錆の厚さ, } \lambda_{1}=\text { 錆の熱伝導率 }
\end{aligned}
$$$$
\text { い屯 } \lambda_{1}=2 \times 10^{-3} \mathrm{cal} / \mathrm{cm}^{\circ} \mathrm{C} \cdot \mathrm{sec}=0.72 \mathrm{kcal} / \mathrm{mhr}^{\circ} \mathrm{C}^{9)}
$$
( $500^{\circ} \mathrm{C}$ の值) とすると, $l_{1} / \lambda_{1}$ は錆が $0.2 \mathrm{~mm}$ の場合, $0.00033 \mathrm{~m}^{2} \mathrm{~K} / \mathrm{W}, 0.5 \mathrm{~mm}$ の場合 $0.00082 \mathrm{~m}^{2} \mathrm{~K} / \mathrm{W}$ となる。 ここで $\alpha_{1}$ は $8,000 \mathrm{~W} / \mathrm{m}^{2} \mathrm{~K}$ (焼入温度 $780^{\circ} \mathrm{C}$ の值) 以上 と考えられるので $\alpha_{1}=8,000 \sim \infty \mathrm{W} / \mathrm{m}^{2} \mathrm{~K}$ として $\alpha_{e}$ を 求めると錆が $0.2 \mathrm{~mm}$ で $2,198 \sim 3,030 \mathrm{~W} / \mathrm{m}^{2} \mathrm{~K}, \quad 0.5$ $\mathrm{mm}$ で 1,058〜 $1,220 \mathrm{~W} / \mathrm{m}^{2} \mathrm{~K}$ となる。このように鋅の 付着により有効熱伝澾係数は大きく低下寸ることがわか る。このことから乾鋼の燒入れ時の場合に高温側で熱伝 達係数が低くなったのは錆の影響と考えられる。なお表 面に付着した錆は冷却中にはく離するため実際の熱伝達 係数はこの值より大きくなったものと考えられる。

$10 \mathrm{Ni}-8 \mathrm{Co}$ 鋼の焼入れ熱処理の場合, Fig. 6 とFig. 8 からわかるよらに目標の $0.5^{\circ} \mathrm{C} / \mathrm{sec}$ 以上の冷却速度は容 易に得ることができる。ぬた全球殼状態でも，内部に生 ずる水蒸気をらまく外部に放出させることにより, 半球 款状態と同じ冷却速度を得ることができる。

最す重要な焼もどし熱処理についても温度管理を十分 行うことにより， $505 \pm 10^{\circ} \mathrm{C}$ の精度を全球殼状態で維持 することができた。

これらの試験結果より，半球殼ならびに全球殼状態の いずれでも， $6,000 \mathrm{~m}$ 深海潜水調査船の耐区球㪍の調質 熱処理が可能であることが明らかになった。

\section{7 結言}

深海潜水調査船の耐圧殼の調質熱処理を確立するため 飞, 内径 $2 \mathrm{~m}$ で板厚 $80 \mathrm{~mm}$ の実物大球㥅模型学用い
て, 半球殼と全球殼の熱処理試験て行った。得られた絬 果をまとめると次のと抢りである。

（1）半球殼ならびに全球殼のいずれの条件でも, $10 \mathrm{Ni}-8 \mathrm{Co}$ 鋼焼入れ熱処理時の $700 \sim 400^{\circ} \mathrm{C}$ の平均冷 却速度は約 $3^{\circ} \mathrm{C} / \mathrm{sec}$ であり, 目標値の $0.5^{\circ} \mathrm{C} / \mathrm{sec}$ を十 分満足できる。

（2）全球殼で焼もどし熱処理を行ら場合でも，保持 温度は $505 \pm 10^{\circ} \mathrm{C}$ 濰持することができ, $10 \mathrm{Ni}-8 \mathrm{C}$ 。 鋼の熱処理条件を踹足できる。

（3）全球款状態で焼入れ焼もどしの熱処理を施した $10 \mathrm{Ni}-8 \mathrm{Co}$ 鋼母材ならびに電子ビーム溶接部の機械的 性質は， $0.2 \%$ 耐力が $126 \mathrm{kgf} / \mathrm{mm}^{2}$ 以上， $0^{\circ} \mathrm{C}$ におけ るシャルピー吸収エネルギーは $16 \mathrm{kgf} \cdot \mathrm{m}$ 以上と良好 な值であった。

（4）全球殸で焼入れ焼もどしの熱処理を行う場合, 工作上問題となる大きな変形は生ぜず，変形防止治具に より形状保持分可能である。

\section{参考文献}

1）横田公男，他：2,000 m 潜水調查船 “してかい 2000”, 三菱重工技報, Vol.18, No. 3 (1981).

2）下山仁，他：深海潜水調査船耐正凯の溶接工作 法に関する研究，三菱重工技報，Vol.13，No. 4 (1976).

3）遠藤倫正，他：雷子ビーム湢接の樑海潜水船耐正 㺃への適用の研究，日本造船学全满文集，第 149 号 (1981).

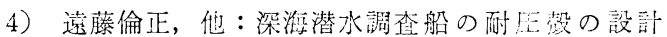
抢よび製作，日本造船学全諭文集，第 148 号 (1980).

5）金沢正午，他：6,000 m 深游調查船用 $10 \mathrm{Ni}-8 \mathrm{Co}$ 銅の特性，製鉄研究，第 284 号 (1975).

6) C. J.Smithells : Metals Reference Book, 5 ih Edition Butterworths, 1976.

7）山口富夫, 他：熱処理時に我引る踻材の冷却速度 の研究, 三菱重工技報, Vol.6, No. 1 (1969).

8) P. J.Schneider : Temperature Response Chart, John Wiley and Sons (1963).

9) J.W. Mellor : Comprehensive Treatise on Inorganic and Theoretical Chemistry, Vol.XIII Fe (Part 2). 